Cognition and Behavior

\title{
Deletion of the Mouse Homolog of CACNA1C Disrupts Discrete Forms of Hippocampal- Dependent Memory and Neurogenesis within the Dentate Gyrus
}

\author{
DStephanie J. Temme, ${ }^{1}$ Ryan Z. Bell, ${ }^{2}$ Grace L. Fisher, ${ }^{2}$ and Geoffrey G. Murphy ${ }^{1,2,3}$ \\ DOI:http://dx.doi.org/10.1523/ENEURO.0118-16.2016 \\ ${ }^{1}$ Neuroscience Graduate Program, University of Michigan, Ann Arbor, Michigan 48109-0069, ${ }^{2}$ Molecular \& Behavioral \\ Neuroscience Institute, University of Michigan, Ann Arbor, Michigan 48109-0069, ${ }^{3}$ Department of Molecular \& \\ Integrative Physiology, School of Medicine, University of Michigan, Ann Arbor, Michigan 48109-0069
}

\begin{abstract}
L-type voltage-gated calcium channels (LVGCCs) have been implicated in various forms of learning, memory, and synaptic plasticity. Within the hippocampus, the LVGCC subtype, $\mathrm{Ca}_{\mathrm{v}} 1.2$ is prominently expressed throughout the dentate gyrus. Despite the apparent high levels of $\mathrm{Ca}_{v} 1.2$ expression in the dentate gyrus, the role of $\mathrm{Ca}_{v} 1.2$ in hippocampal- and dentate gyrus-associated forms of learning remain unknown. To address this question, we examined alternate forms of hippocampal-dependent associative and spatial memory in mice lacking the mouse ortholog of CACNA1C (Cacna1c), which encodes $\mathrm{Ca}_{\mathrm{v}} 1.2$, with dentate gyrus function implicated in difficult forms of each task. We found that while the deletion of $\mathrm{Ca}_{V} 1.2$ did not impair the acquisition of fear of a conditioned context, mice lacking $\mathrm{Ca}_{\mathrm{v}} 1.2$ exhibited deficits in the ability to discriminate between two contexts, one in which the mice were conditioned and one in which they were not. Similarly, $\mathrm{Ca}_{\mathrm{v}} 1.2$ knock-out mice exhibited normal acquisition and recall of the location of the hidden platform in a standard Morris water maze, but were unable to form a memory of the platform location when the task was made more difficult by restricting the number of available spatial cues. Within the dentate gyrus, pan-neuronal deletion of $\mathrm{Ca}_{v} 1.2$ resulted in decreased cell proliferation and the numbers of doublecortin-positive adult-born neurons, implicating $\mathrm{Ca}_{\mathrm{v}} 1.2$ in adult neurogenesis. These results suggest that $\mathrm{Ca}_{\mathrm{v}} 1.2$ is important for dentate gyrus-associated tasks and may mediate these forms of learning via a role in adult neurogenesis and cell proliferation within the dentate gyrus.
\end{abstract}

Key words: L-type voltage-gated calcium channel; pattern completion; pattern separation

\section{Significance Statement}

Recent genome-wide association studies have implicated the gene CANA1C, which encodes the L-type voltage-gated calcium channel $\mathrm{Ca}_{\mathrm{v}} 1.2$ as a risk factor for psychiatric disease. Here we examine mice lacking the mouse ortholog of CANA1C. We find that, while seemingly normal, these mice lack the ability to successfully learn tasks that require the discrimination of environmental cues or in which the cues are limited. This type of learning, often referred to as pattern separation/completion, is thought to require the birth and survival of neurons in the dentate gyrus subregion of the hippocampus. Interestingly, mice lacking $\mathrm{Ca}_{\mathrm{v}} 1.2$ exhibit reduced neurogenesis in this brain region. Our results suggest an intriguing link among a psychiatric risk allele, neurogenesis, and pattern separation/completion.

Received May 13, 2016; accepted October 26, 2016; First published November 09, 2016.

The authors declare no competing financial interests.
Author contributions: S.J.T. and G.G.M. designed the research; S.J.T., R.Z.B. and G.L.F. performed the research; S.J.T. and G.G.M. wrote the paper. 


\section{Introduction}

In neurons, activity-dependent increases in intracellular calcium are mediated in large part by calcium influx through L-type voltage-gated calcium channels (LVGCCs). As a class of channels, the LVGCCs have been implicated in a wide range of neurophysiological functions, including the regulation of intrinsic neuronal excitability (Kaczorowski, 2011), synaptic plasticity (Kapur et al., 1998; Zakharenko et al., 2001), and transcriptional activation (Deisseroth et al., 1998), as well as cognition (Bauer et al., 2002; Cain et al., 2002; Davis and Bauer, 2012).

Of the four major LVGCC subtypes, $\mathrm{Ca}_{\mathrm{V}} 1.2$ and $\mathrm{Ca}_{\mathrm{V}} 1.3$ are abundantly expressed within the mammalian brain. However, differential expression patterns (Hell et al., 1993) and biophysical characteristics (Lipscombe et al., 2004) suggest that $\mathrm{Ca}_{\mathrm{v}} 1.2$ and $\mathrm{Ca}_{\mathrm{v}} 1.3$ may have distinct roles in neuronal function and behavior. In the hippocampus, $\mathrm{Ca}_{\mathrm{v}} 1.3$ is expressed in the soma and proximal dendrites throughout the hippocampus, while $\mathrm{Ca}_{v} 1.2$ is broadly expressed throughout CA3 and the dentate gyrus, with limited expression elsewhere (Hell et al., 1993; Marschallinger et al., 2015). In vitro studies of neuronal development have implicated LVGCCs in cell proliferation and neurogenesis (D'Ascenzo et al., 2006; Piacentini et al., 2008; Brustein et al., 2013). Additionally, $\mathrm{Ca}_{v} 1.2$ has also been tied to the survival of adult-born neurons in the dentate gyrus in vivo (Lee et al., 2016). Previously, it has been demonstrated that $\mathrm{Ca}_{v} 1.3$ is required for the consolidation of contextual fear (McKinney and Murphy, 2006), and a recent report (Marschallinger et al., 2015) suggests that $\mathrm{Ca}_{\mathrm{v}} 1.3$ is required for object location discrimination. Conversely, individual investigations of $\mathrm{Ca}_{\mathrm{v}} 1.2$ have yielded mixed results. Deletion of the gene Cacna1c (the mouse ortholog of the CACNA1C gene), which encodes $\mathrm{Ca}_{\mathrm{v}} 1.2$ did not affect contextual fear learning (McKinney et al., 2008; Langwieser et al., 2010) but did result in remote spatial learning deficits (White et al., 2008). Additionally, deficits in the visible platform discrimination water maze and the labyrinth maze were observed in a $\mathrm{Ca}_{v} 1.2$ conditional knock-out mouse (Moosmang et al., 2005). In light of these behavioral re-

This research was supported by the National Science Foundation through a Graduate Research Fellowship and a Rackham Merit Fellowship (Grant 100000001) through the University of Michigan Rackham Graduate School (to S.J.T.); National Institute on Aging/National Institutes of Health Grant R01-AG028488 (to G.G.M.); and the University of Michigan Endowment for Basic Science (to G.G.M.)

S.J. Temme's present address: Lieber Institute of Brain Development, Institute of Cell Engineering, Department of Neurology, Johns Hopkins University School of Medicine, 706 Miller Research Building, 733 Broadway, Baltimore, MD 21205.

Acknowledgments: We thank Dr. Jacob Temme for sharing MATLAB code and helpful assistance with the image analysis.

Correspondence should be addressed to Dr. Geoffrey G. Murphy, University of Michigan, 5037 Biomedical Science Research Building, 109 Zina Pitcher Place, Ann Arbor, Ml 48109-2200. E-mail: murphyg@umich.edu.

DOI:http://dx.doi.org/10.1523/ENEURO.0118-16.2016

Copyright (C) 2016 Temme et al.

This is an open-access article distributed under the terms of the Creative Commons Attribution 4.0 International, which permits unrestricted use, distribution and reproduction in any medium provided that the original work is properly attributed. sults and the differential expression of $\mathrm{Ca}_{\mathrm{v}} 1.2$ in the hippocampus, we hypothesized that $\mathrm{Ca}_{\mathrm{v}} 1.2$ might be important in hippocampal-dependent learning in a uniquely task- and subregion-dependent manner. Unlike other regions of the hippocampus, the dentate gyrus is the location of continual cell proliferation into adulthood (Altman and Das, 1965; Gage, 2002). Adult born neurons within the dentate gyrus have been linked to unique forms of hippocampal-dependent learning (Gould et al., 1999; Shors et al., 2002; Winocur et al. 2006). While lesion studies have demonstrated a role of the hippocampus in proper contextual fear conditioning (Logue et al., 1997; Maren et al., 1997) and the standard water maze (Logue et al., 1997), disruptions in neurogenesis within the dentate gyrus do not impair the ability of animals to acquire these tasks (Shors et al., 2002; Jaholkowski et al., 2009). In contrast, more difficult learning tasks appear to rely on the dentate gyrus and are impaired when neurogenesis is decreased (Shors et al., 2002).To evaluate the role of $\mathrm{Ca}_{\mathrm{V}} 1.2$ in difficult versus simple learning tasks, we used $\mathrm{Ca}_{\mathrm{V}} 1.2$ conditional knock-out $\left(\mathrm{Ca}_{\mathrm{V}} 1.2^{\mathrm{KOO}}\right)$ mice in which Cre was driven throughout neuronal populations (Zhu et al., 2001; Cui et al., 2008). These mice were examined for deficits in simple and complex versions of spatial and contextual learning tasks. We found that $\mathrm{Ca}_{\mathrm{v}} 1.2^{\mathrm{CKO}}$ mice learned normally in simple tasks, such as context fear conditioning and the standard Morris water maze, but exhibited significant deficits in complex tasks, including context discrimination and the limited cues water maze. Additionally, $\mathrm{Ca}_{\mathrm{v}} 1.2^{\mathrm{cKO}}$ mice were found to have a decrease in cell proliferation and decreased numbers of immature neurons in the dentate gyrus. Several genomewide association studies have linked CACNA1C to a wide variety of psychiatric disorders (Sklar et al., 2008), raising the intriguing possibility that disruptions of $\mathrm{Ca}_{\mathrm{V}} 1.2$ function or expression may play a significant role not only in cognition, but also in neuropsychiatric disorders via modulation adult neurogenesis and dentate gyrus function.

\section{Materials and Methods}

\section{Mice}

All studies were conducted using naive mice. Mice were 3-7 months of age at the time of each behavioral experiment and 4 months of age at the time of tissue collection. Approximately equal numbers of males and females were used per genotype. Due to the absence of sex differences, all data are presented as an average of both male and female mice. Mice in each line were housed by sex and in groups of three to five. Throughout the course of all experiments, the investigator remained blind to the genotype of the mice. Mice were maintained in microisolation cages with a 14/10 $\mathrm{h}$ light/dark cycle, an average ambient temperature of $22^{\circ} \mathrm{C}$, and ad libitum access to food and water. All experiments were conducted according to the National Institutes of Health guidelines for animal care and were performed in accordance with the University of Michigan Institutional Animal Care and Use Committee regulations. Conditional knock-out mice with neuronspecific deletion of $\mathrm{Ca}_{\mathrm{v}} 1.2\left(\mathrm{Ca}_{\mathrm{v}} 1.2^{\mathrm{cKO}}\right)$ and their wild-type littermates were used. Mice used in this study were on a 
C57BL/6:129SvEv F2 genetic background. Mice with a floxed $\mathrm{Ca}_{\mathrm{v}} 1.2$ exon 2 allele $\left(\mathrm{Ca}_{\mathrm{v}} 1.2^{\mathrm{f} /+}\right.$ or $\left.\mathrm{Ca}_{\mathrm{v}} 1.2^{\mathrm{f} / \mathrm{f}}\right)$ and maintained on a 129SvEv genetic background were first bred to transgenic mice expressing the Cre recombinase regulated by the synapsin 1 promoter $\left(\mathrm{Syn} 1-\mathrm{Cre}^{\mathrm{Cre} /+}\right)$ and were maintained on a C57BL/6 background, producing an F1 cross. Using nonlittermate offspring from the F1 cross, heterozygous-floxed, Cre-positive mice $\left(\mathrm{Ca}_{\mathrm{v}} 1.2^{\mathrm{f} /+} \mathrm{Syn} 1\right.$ $\mathrm{Cre}^{\mathrm{Cre} /+}$ ) were then crossed with heterozygous-floxed, Cre-negative mice $\left(\mathrm{Ca}_{\mathrm{v}} 1.2^{\mathrm{f} /+}\right.$ Syn1-Cre $\left.{ }^{+/+}\right)$to produce homozygous-floxed, Cre-positive $\left(\mathrm{Ca}_{\mathrm{v}} 1.2^{\mathrm{f} / \mathrm{f}}\right.$ Syn1$\mathrm{Cre}^{\mathrm{Cre} /{ }^{+}}$) conditional knock-out mice as well as mice categorized as wild-type or control. Mice were considered to be wild type if they were Cre negative and lacked the floxed alleles $\left(\mathrm{Ca}_{\mathrm{v}} 1.2^{+/+}\right.$Syn1-Cre $\left.{ }^{+/+}\right)$. Mice were considered to be a control if they were homozygous or heterozygous for the floxed allele and Cre negative $\left(\mathrm{Ca}_{\mathrm{v}} 1.2^{\mathrm{f} / \mathrm{f}}\right.$ Syn1-Cre ${ }^{+/+} ; \mathrm{Ca}_{\mathrm{v}} 1.2^{\mathrm{f} /+}$ Syn1-Cre $\left.{ }^{+/+}\right)$, or if they were Cre positive but lacked the floxed alleles $\left(\mathrm{Ca}_{\mathrm{v}} 1.2^{+/+}\right.$ Syn1-Cre ${ }^{\mathrm{Cre} /+}$ ). Because no significant differences were detected between the various control groups and true wild-type mice, these groups were collapsed into a single group, which we refer to simply as "wild-type" throughout the rest of the article.

\section{Pavlovian fear conditioning}

Fear-conditioning experiments were conducted as previously described (Temme et al., 2014). Fear-conditioning chambers were composed of clear acrylic backs and doors, aluminum sides, stainless steel grid floors with one-eighth inch spaces, and stainless steel drop pans (Med Associates). Throughout experimentation, chambers and floor pans were cleaned with $70 \%$ ethanol. Chambers were illuminated using room lights set at 150 W. Footshocks were administered through the grid via solid-state shock scramblers and electronic constantcurrent shock sources. Shocks were controlled by a desktop PC running Actimetrics FreezeFrame software. The behavior of each mouse was recorded and digitized using individual cameras mounted above each chamber using the Actimetrics FreezeFrame software. Mice were fear conditioned to a context using one training session per day for $2 \mathrm{~d}$. Each fear-conditioning session consisted of 3 min of context exposure to the training chamber followed by three unsignaled footshocks $(0.5 \mathrm{~mA}, 2 \mathrm{~s})$ with $30 \mathrm{~s}$ between footshocks. Mice were removed from the training chamber $30 \mathrm{~s}$ after the last footshock. Twenty-four hours after the last training session, mice were tested for fear of the trained context using 5 min of context exposure.

\section{Context discrimination}

During context discrimination, mice were trained to discriminate between two contexts through exposure to both contexts each day for $10 \mathrm{~d}$, separated by a minimum of $6 \mathrm{~h}$. One context was termed context A, and consisted of the fear-conditioning chamber as described above, room lights at $150 \mathrm{~W}$, a scent of $70 \%$ ethanol, and white noise. The second context was termed context $B$, and was composed of red room lights, a scent of $2 \%$ acetic acid, no white noise, and the floor in the fear-conditioning chamber was covered with a speckled rubber floor covering. In context $A$, mice were trained each day using 3 min of context exposure followed by one unsignaled footshock $(2 \mathrm{~s}, 0.5 \mathrm{~mA})$. Mice were removed from the conditioning chambers $30 \mathrm{~s}$ after the footshock. In context B, mice received context exposure for 3 min and $32 \mathrm{~s}$, which is comparable to the time spent in context $A$ with no unsignaled footshock. The order of exposure to contexts $A$ and $B$ was alternated each day. Mice were tested for their fear of contexts $A$ and $B$ on day 10 using an exposure of $3 \mathrm{~min}$ and $30 \mathrm{~s}$ to each context in the absence of a footshock.

\section{Standard Morris water maze}

The water maze was composed of a round white acrylic pool that was $1.2 \mathrm{~m}$ in diameter. Throughout experimentation, the pool was filled with water that was made opaque using nontoxic white tempera paint and heated to $27^{\circ} \mathrm{C}$. A round platform made of clear acrylic and measuring $10 \mathrm{~cm}$ in diameter was submerged just below the surface of the water. Mice were tracked in twodimensional space within the water maze using a digital camera mounted above the pool. Digital tracking and off-line analysis were accomplished with Actimetrics Water Maze 3 software. Mice were allowed to find the hidden platform using two back-to-back training sessions per day for $9 \mathrm{~d}$. For each session, mice were released pseudorandomly into the maze facing the outside of the maze, and the time it took them to find the platform was recorded. For all sessions, mice were given $60 \mathrm{~s}$ to find the platform, after which point mice would be guided to the platform. Each day, mice were individually placed on the platform for $15 \mathrm{~s}$ before the start of session 1 and session 2. After the completion of each training session, mice were allowed to remain on the platform for a period of 15 $s$ before being placed back in their home cage. Mice were tested for their memory of the platform location using a probe test $24 \mathrm{~h}$ after the last day of training. During the probe test the platform is removed and the amount of time mice spend within a specific vicinity of the platform is measured. The probe test was performed by releasing each mouse individually into the pool at a point opposite to the original platform location. Mice were then allowed to explore the maze for a period of $60 \mathrm{~s}$ before being removed near the original platform location.

\section{Limited cues water maze}

During the limited cues water maze, a blue plastic barrier was used to encircle the entire water maze, blocking all visual cues in the room except for four discreet visual cues that were mounted evenly around the maze. Mice were trained to the limited cues water maze using two sessions per day for $12 \mathrm{~d}$. Aside from the increase in number of training days, training was conducted in the same manner as in the standard Morris water maze. Mice were tested for their memory of the platform location using the following two probe tests: one at the beginning of day 9 of experimentation, and one $24 \mathrm{~h}$ after the last day of training. Probe tests were conducted as described for the standard Morris water maze. 


\section{Bromodeoxyuridine labeling}

Mice were administered bromodeoxyuridine (BrdU; 100 $\mathrm{mg} / \mathrm{kg}$ ) dissolved in sterile PBS, via intraperitoneal injections, once a day for $5 \mathrm{~d}$ in order to assess cell birth rates in the dentate gyrus. All BrdU solutions for injection were made fresh daily at a concentration of $10 \mathrm{mg} / \mathrm{mL}$ and a $\mathrm{pH}$ of $\sim 7.4$, with the addition of $\mathrm{NaOH}$ if necessary. For each injection, mice were anesthetized using isoflurane prior to each BrdU injection and monitored until they recovered. Approximately $24 \mathrm{~h}$ after the last injection, mice were perfused using $0.9 \%$ sodium chloride followed by icecold $4 \%$ paraformaldehyde in PBS. Brains were then removed and postfixed overnight in $4 \%$ paraformaldehyde, after which time they were transferred to $30 \%$ sucrose for a minimum of $48 \mathrm{~h}$ or until saturation of the brain in sucrose allowed the brains to sink in solution. The brains were then frozen on dry ice, and coronal slices were made at $40 \mu \mathrm{m}$ and stored, free floating, in cryoprotectant buffer at $-20^{\circ} \mathrm{C}$ for later use. Brains sections were labeled for BrdU expression using immunofluorescent histochemistry. Selected tissue sections were rinsed of cryoprotectant buffer using an overnight wash in Tris, $\mathrm{pH}$ 7.4. Sections were then washed using Tris-buffered saline (TBS), $\mathrm{pH} 7.4$, and incubated in $2 \mathrm{M} \mathrm{HCl}$ for $30 \mathrm{~min}$ at $32^{\circ} \mathrm{C}$ to denature the DNA. Sections were then neutralized using $0.1 \mathrm{~m}$ sodium borate for $10 \mathrm{~min}, \mathrm{pH}$ 8.5. Following neutralization, sections were again rinsed in TBS followed by incubation in blocking buffer (10\% normal horse serum and $0.3 \%$ Triton $\mathrm{X}-100$ in TBS) for $1 \mathrm{~h}$ and incubation in sheep anti-BrdU (1:250; catalog \#ab1893, Abcam) in blocking buffer overnight at $4^{\circ} \mathrm{C}$. The following day, slices were washed in TBS and incubated for $1.5 \mathrm{~h}$ in donkey anti-sheep (1:200; Alexa Fluor 594; catalog \#ab150184, Abcam) at room temperature. Once labeled, sections were washed in TBS, mounted, and coverslipped using anti-fade containing DAPI (ProLong Gold; catalog \#P36931, Molecular Probes).

\section{Doublecortin labeling}

Doublecortin studies were performed using tissue collected from BrdU-injected mice. Tissue sections were washed in a $1 \times$ Tris buffer, $\mathrm{pH} 7.6$, prior to incubation in $1 \% \mathrm{H}_{2} \mathrm{O}_{2}$ for 30 min to quench endogenous peroxidase activity. Sections were then washed in the $1 \times$ Tris buffer, and cells were permeabilized using $0.1 \%$ Triton in Tris for $15 \mathrm{~min}$. Sections were then incubated in a solution of $0.05 \%$ bovine serum albumin (BSA) and $0.1 \%$ Triton in Tris for 15 min prior to blocking in a blocking buffer solution of $0.05 \%$ BSA, $10 \%$ natural horse serum, and $0.1 \%$ Triton $\mathrm{X}-100$ in Tris for $1 \mathrm{~h}$. After blocking, tissue was rinsed in $0.1 \%$ Triton $X-100$ in Tris and $0.1 \%$ Triton $X-100$ with $0.05 \%$ BSA in Tris for a period of 15 min each prior to incubation in rabbit anti-doublecortin (1:1000; catalog \#AB18723, Abcam) in blocking buffer solution overnight at $4{ }^{\circ} \mathrm{C}$. Sections were again rinsed in $0.1 \%$ Triton X-100 in Tris and $0.1 \%$ Triton X-100 with $0.05 \%$ BSA in Tris for a period of 15 min each prior to incubation in a biotinylated anti-rabbit IgG (1:200; catalog \#BA-1000, Vector Laboratories) for $2 \mathrm{~h}$ at room temperature. Sections were then briefly rinsed in $0.1 \%$ Triton $X-100$ with
$0.05 \%$ bovine serum albumin in Tris and incubated with avidin-biotin complex (1:1000; ABC Kit, catalog \#PK6100 , Vector Laboratories) in the same solution for a period of $1 \mathrm{~h}$. Tissue was then incubated in diaminobenzidene with nickel according to manufacturer instructions (catalog \#SK-4100, Vector Laboratories) for $\sim 2 \mathrm{~min}$ and washed four times in $1 \times$ Tris. Sections were then mounted and coverslipped.

\section{Cell counting}

Brain slices labeled for BrdU and doublecortin were imaged at $10 \times$ magnification using a $1344 \times 1024 \mathrm{CCD}$ camera (Orca-ER, Hamamatsu) on a DMI6000B Microscope (Leica). Images were subsequently analyzed offline using ImageJ (version 1.48, National Institutes of Health). Individual images of the granule cell layer were concatenated, and a region of interest (ROI) consisting of labeled cells within $35 \mu \mathrm{m}$ of the subgranular zone was selected and straightened. The number of cells positive for BrdU or doublecortin was then counted visually by an experimenter blind to genotype and divided by the ROI, producing a density value. Density values were then normalized to the density of BrdU-positive or doublecortinpositive cells in wild-type mice.

\section{Dentate gyrus granular cell layer measurements}

The overall width of the granular cell body layer of the dentate gyrus was assessed using MATLAB code (modifed from Temme et al., 2015), which was designed to calculate the average width of a region of interest. The collection of sections was standardized across mice, with four slices analyzed per mouse spaced evenly throughout the dentate gyrus, specifically, every 12 th slice of $40 \mu \mathrm{m}$ slices starting from the anterior end. After acquisition, slices were stained for DAPI to identify the cell body layer. Images of each slice was taken at $10 \times$ magnification and loaded into a predesigned MATLAB code that identifies the DAPI-labeled cell body layer for the apex, and the superior and inferior blades of the dentate gyrus. Once the cell body layer is identified, the program calculates the width of each blade per micrometer (pixel density) along the entire length of each blade respectively. The program then outputs the average width value per blade. These outputted values are then averaged per dentate gyrus, then per mouse, then per genotype.

\section{Statistical analysis}

The analysis of behavioral experiments was performed using repeated-measures ANOVAs, two-way ANOVAs, and planned unpaired $t$ tests comparing $\mathrm{Ca}_{\mathrm{V}} 1.2^{\mathrm{cKO}}$ mice with their wild-type counterparts. Learning across fearconditioning discrimination ratio, the standard Morris water maze, the limited cues water maze, and the visible platform test in the limited cues water maze were analyzed using repeated-measures ANOVA, with genotype and training as factors. Discrimination freezing was analyzed using a repeated-measures ANOVA with genotype and context as factors. Platform preference during water maze probe tests was analyzed using a one-sample $t$ test was used, with chance (25\%) set as the hypothetical mean. The context test and differences in BrdU and dou- 
blecortin cell densities were analyzed using an unpaired $t$ test.

\section{Results}

\section{Conditional deletion of $\mathrm{Ca}_{\mathrm{v}} \mathbf{1 . 2}$ does not affect simple} hippocampal-dependent learning

While mice in which the deletion of $\mathrm{Ca}_{v} 1.2$ is restricted to glutamatergic neurons in the forebrain do not exhibit deficits in either contextual fear conditioning (McKinney et al., 2008) or the Morris water maze $24 \mathrm{~h}$ after training (White et al., 2008), it is possible that the deletion of $\mathrm{Ca}_{v} 1.2$ in neurons throughout the brain could generate deficits in these forms of learning. Using the synapsin1cre $\mathrm{Ca}_{\mathrm{v}} 1.2^{\mathrm{cKO}}$ mice, we investigated the role of $\mathrm{Ca}_{\mathrm{v}} 1.2$ in contextual fear conditioning. Mice were fear conditioned to a context across $2 \mathrm{~d}$ using one session per day. Each session consisted of $3 \mathrm{~min}$ of context exposure followed by three unsignaled footshocks $(0.5 \mathrm{~mA}, 2 \mathrm{~s})$ with an intershock interval of $30 \mathrm{~s}$. The acquisition and consolidation of fear across training days was analyzed by comparing the average percentage of freezing during the 3 min of context exposure for each day (Fig. 1A). The analysis of context conditioning using a two-way ANOVA found a significant effect of training day $\left(F_{(1,32)}=66.58, p\right.$ $<0.0001)$, but not of genotype $\left(F_{(1,32)}=0.12, p=0.73\right)$. Both wild-type and $\mathrm{Ca}_{v} 1.2^{\mathrm{KKO}}$ mice showed an increase in freezing across training with an average percentage of freezing of $0.2 \%$ on day 1 and $34 \%$ on day 2 in wild-type mice, and $1 \%$ on day 1 and $31 \%$ on day 2 in $\mathrm{Ca}_{v} 1.2^{\mathrm{cKO}}$ mice. Twenty-four hours after the last training session, mice were tested for their fear of the context using $5 \mathrm{~min}$ of context exposure. The analysis of freezing behavior during context testing using an unpaired $t$ test found no significant difference between genotypes $(p=0.86)$ with an average percentage of freezing of $63 \%$ in wild-type mice and $61 \%$ in $\mathrm{Ca}_{v} 1.2^{\mathrm{cKO}}$ mice (Fig. 1B). These data suggest normal fear conditioning in mice lacking $\mathrm{Ca}_{v} 1.2$.

To further explore the effects of $\mathrm{Ca}_{v} 1.2$ on hippocampal-dependent learning, we tested $\mathrm{Ca}_{\mathrm{v}} 1.2^{\mathrm{cKO}}$ mice in the standard Morris water maze task (Morris, 1984). In the standard Morris water maze, mice learn to use the complex spatial cues located distal to the water maze to locate a hidden platform placed just below the surface of the pool (Fig. 2A). Mice were trained to find the location of the hidden platform using two sessions per day for $9 \mathrm{~d}$. During each session, mice were pseudorandomly released into the pool and allowed $60 \mathrm{~s}$ to locate the hidden platform. Approximately $24 \mathrm{~h}$ after the last day of training, mice were tested for their spatial memory of the platform location using a probe test. Analysis of the latency to find the hidden platform using a repeatedmeasures ANOVA exhibited a significant reduction in latency to find the platform across training days $\left(F_{(8,280)}=\right.$ 25.85, $p<0.0001)$ with a decrease in average latency from 50.0 to $23.4 \mathrm{~s}$ in wild-type mice and 53.6 to $19.5 \mathrm{~s}$ in $\mathrm{Ca}_{\mathrm{v}} 1.2^{\mathrm{ckO}}$ mice, but no difference between genotypes $\left(F_{(1,40)}=3.147, p=0.09\right.$; Fig. $\left.2 B\right)$.

During the probe test, mice were analyzed for the percentage of time spent in the location in which the platform had previously been located. Exploration in the probe test

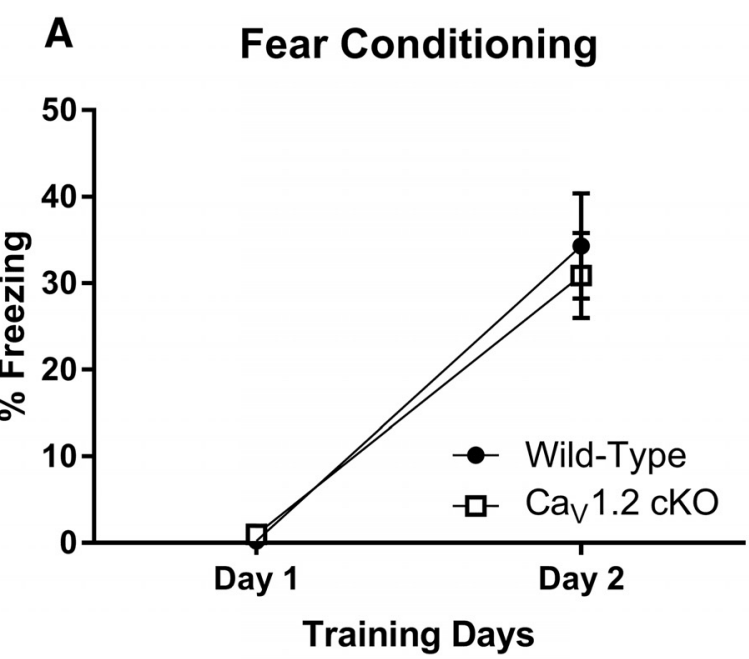

B Context Fear Test

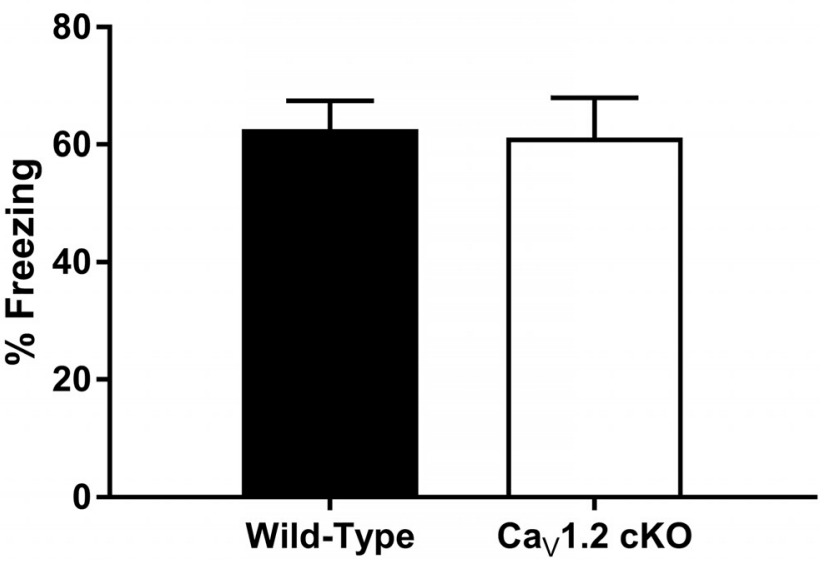

Figure 1. Neuronal deletion of $\mathrm{Ca}_{v} 1.2$ does not impair fear acquisition or consolidation to a conditioned context. Mice were fear conditioned to a context using three unsignaled footshocks per day for 2 d. $\boldsymbol{A}$, Both $\mathrm{Ca}_{\mathrm{v}} 1.2$ conditional knock-out mice $(n=$ $17)$ and wild-type mice $(n=17)$ exhibited a significant enhancement in freezing in response to the conditioned context between days 1 and 2 of training. $\boldsymbol{B}$, When tested for their fear of the context, $\mathrm{Ca}_{\mathrm{V}} 1.2$ conditional knock-out mice exhibited high levels of freezing comparable to those of wild-type mice. Data are represented as the mean \pm SEM.

was analyzed by splitting the maze into four quadrants with the original platform location in the center of one quadrant, titled the target quadrant. The percentage of time spent in the target quadrant was then compared to a chance level of $25 \%$. During the probe test, both $\mathrm{Ca}_{\mathrm{v}} 1.2^{\mathrm{cKO}}$ mice and their wild-type littermates spent a significant percentage of time in the target quadrant compared with chance $(p<0.0001$ and $p<0.0001$, respectively, one sided $t$ test; Fig. 2C). Similarly, the percentage of time that the $\mathrm{Ca}_{\mathrm{v}} 1.2^{\mathrm{cKO}}$ mice and their wild-type littermates spent in the target quadrant was the same (unpaired $t$ test, $p=0.844$ ). This is further illustrated using a heat map to illustrate the average percentage of time spent throughout the probe test (Fig. 2D). Examination of 
A

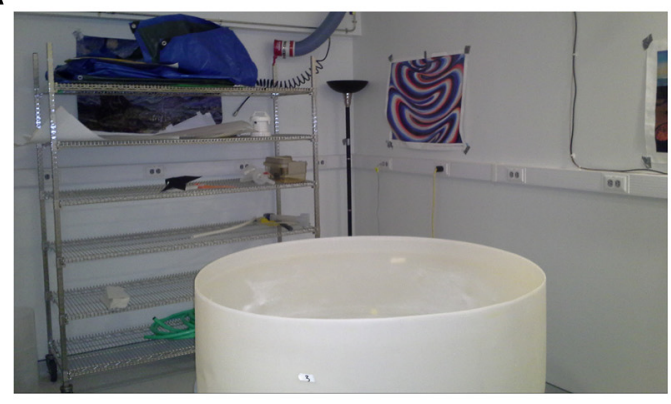

B

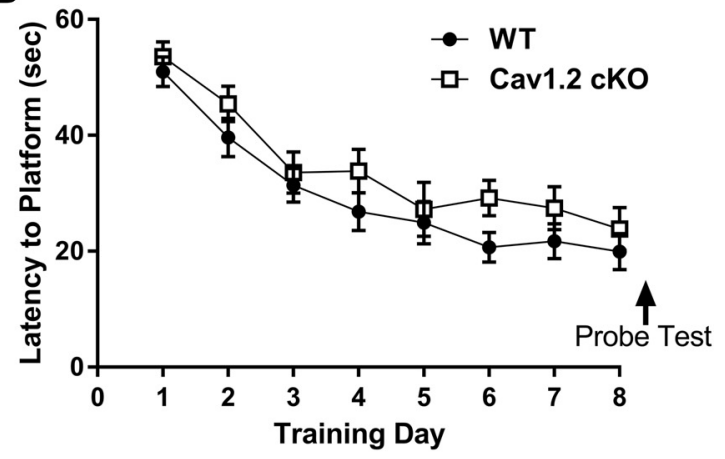

C

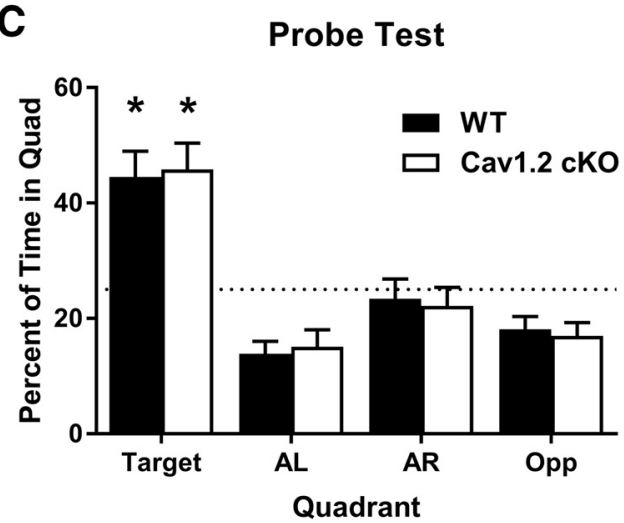

Training

D

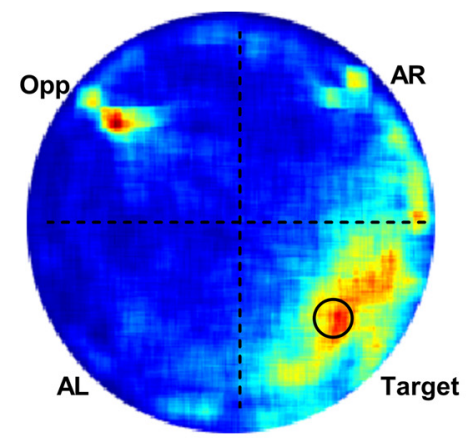

Figure 2. Neuronal deletion of $\mathrm{Ca}_{\mathrm{v}} 1.2$ does not impair spatial learning in the standard Morris water maze. $\boldsymbol{A}$, Mice were trained to find a hidden platform in a Morris water maze using numerous spatial cues around the room. Mice were trained across $8 \mathrm{~d}$ with a probe test on day 9. $\boldsymbol{B}$, Both $\mathrm{Ca}_{\mathrm{V}} 1.2$ conditional knock-out mice $(n=18)$ and wild-type mice $(n=24)$ exhibited a significant decline in the latency to find the hidden platform across training days. $\boldsymbol{C}$, When probed for their memory of the platform location, both $\mathrm{Ca}_{\mathrm{V}} 1.2$ conditional knock-out mice and wild-type mice spend significantly more time in the target quadrant than chance [*p $<0.0001$, single-group $t$ test with a hypothetical mean of $25 \%$ (indicated by dashed line)]. $\boldsymbol{D}$, Representation of the time spent throughout the water maze during the probe test using a heat map illustrated a strong preference for the platform location and the target quadrant, with an additional strong signal at the location at which mice were released into the pool.

the heat map revealed a large period of time spent in the target quadrant where the hidden platform was located. A significant amount of time spent in the opposite quadrant was also noted, which corresponded with the location at which mice were released into the pool and likely represents the brief period during which the mice spent orienting themselves. Similar to previously published literature, these data suggest that $\mathrm{Ca}_{\mathrm{v}} 1.2$ is not involved in spatial learning in the standard Morris water maze when assessed $24 \mathrm{~h}$ after training (White et al., 2008). Together with the data demonstrating no effects of the deletion of $\mathrm{Ca}_{\mathrm{v}} 1.2$ on fear conditioning to a context, this suggests that $\mathrm{Ca}_{\mathrm{v}} 1.2$ does not affect these forms of learning and memory, which previously were found to be neurogenesis-independent forms of hippocampal-dependent learning tasks (Shors et al., 2002; Jaholkowski et al., 2009).

\section{Neuronal deletion of $\mathrm{Ca}_{\mathbf{v}} \mathbf{1 . 2}$ produces deficits in dentate gyrus-associated learning tasks}

To determine whether neuronal deletion of $\mathrm{Ca}_{\mathrm{v}} 1.2$ produces deficits in more difficult versions of hippocampaldependent learning, $\mathrm{Ca}_{\mathrm{V}} 1.2^{\mathrm{cKO}}$ mice were tested in the following two alternate versions of contextual and spatial learning: context discrimination and a limited cues version of the Morris water maze. During context discrimination, mice were trained to discriminate between two contexts, contexts $A$ and context $B$, through exposure to each context once a day for $10 \mathrm{~d}$ (Fig. 3A). For $9 \mathrm{~d}$, context A, was paired with an unsignaled footshock (0.5 mA, $2 \mathrm{~s})$, and on day 10 , mice were placed in context $A$, but no footshock was given. For all $10 \mathrm{~d}$, mice were placed in context $B$ for the same period of time as context A without a footshock, and the order in which the mice experienced each context was counterbalanced. Discrimination between contexts was calculated as a discrimination ratio, calculated as the average percentage of freezing in the trained context divided by the total percentage of freezing in both contexts per day. Data were analyzed as the average of every $2 \mathrm{~d}$ to control for time-of-day effects. Due to the order in which the contexts were presented, mice were analyzed for a freezing response to context $A$ on day 1 prior to the first pairing of the context and footshock, while the first exposure to context B occurred after the pairing of context $A$ with the footshock. Therefore, the context discrimination ratio from days 1-2 do not accurately represent the measurement of discrimination between contexts. Analysis of context discrimination ra- 
A Discrimination Training

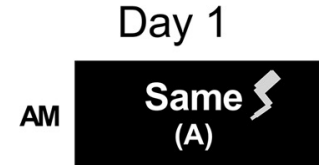

Day 2

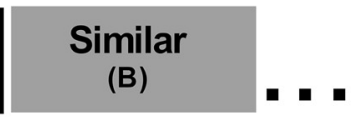

$$
\text { PM }
$$

Similar

(B)

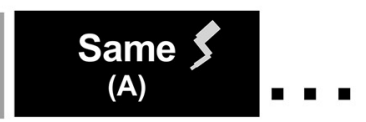

B

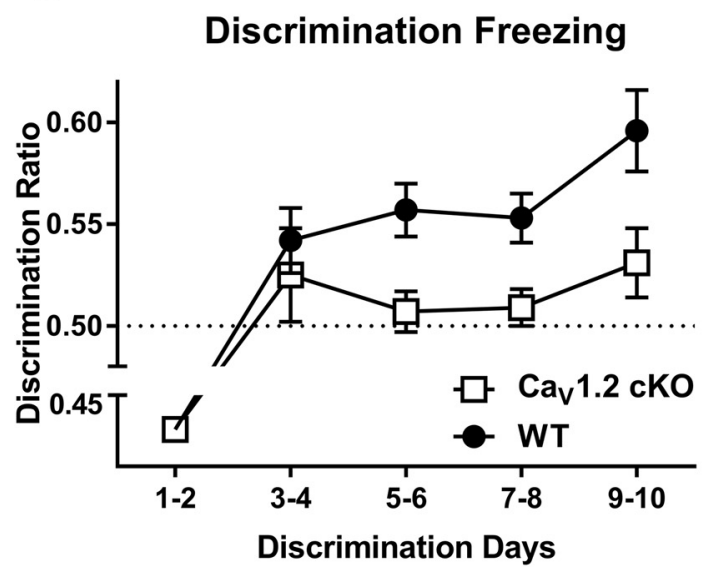

Day 9

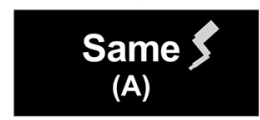

Similar

(B)
Day 10

Similar

(B)

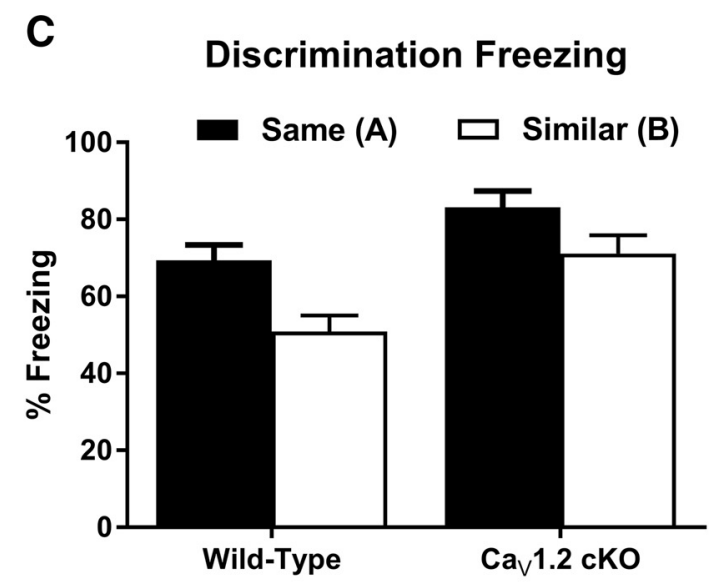

Figure 3. $\mathrm{Ca}_{\mathrm{v}} 1.2$ conditional knock-out mice exhibit significant deficits in context discrimination. $\boldsymbol{A}$, Mice were trained to discriminate between two similar contexts through context exposure to each context once a day for $10 \mathrm{~d}$ with one context, and the same context, paired with a footshock. Context discrimination throughout training was assessed using a discrimination ratio, with a ratio of 0.5 representing a lack of discrimination between the two contexts. $\boldsymbol{B}$, While wild-type mice $(n=18)$ displayed a significant discrimination ratio $>0.5$ (indicated by a dashed line) by day 3-4 of training, $\mathrm{Ca}_{v} 1.2$ conditional knock-out mice $(n=17)$ failed to show a significant discrimination ratio until days 9-10. Additionally, analysis between genotypes revealed a significant deficit in context discrimination in $\mathrm{Ca}_{v} 1.2$ conditional knock-out mice compared with wild-type mice. $\boldsymbol{C}$, Comparison of average freezing levels between the trained context, $\mathrm{A}$, and the similar context, $\mathrm{B}$, on days 9-10 of training reveal revealed a significant effect of genotype and context, but no interaction between genotype and context. Data are represented as the mean \pm SEM.

tios across training days using a two-way repeatedmeasures ANOVA revealed a significant effect of genotype $\left(F_{(1,330)}=5.183, p=0.0294\right)$ with discrimination deficits in $\mathrm{Ca}_{\mathrm{V}} 1.2^{\mathrm{CKO}}$ mice (Fig. $3 B$ ). While wild-type mice showed a significant discrimination ratio $>0.5$ starting on days 3-4 of context discrimination $(p=0.0182$, onegroup $t$ test), $\mathrm{Ca}_{\mathrm{v}} 1.2^{\mathrm{cKO}}$ mice exhibited discrimination ratios that were no better than chance up until days 9-10 of training ( $p=0.0159$, one-group $t$ test). Consistent with this observation, the analysis of context discrimination through the comparison of raw freezing levels between the two contexts during the discrimination test using a two-way repeated-measures ANOVA revealed a significant effect of genotype $\left(F_{(1,33)}=9.231, p=0.0046\right)$ and context $\left(F_{(1,33)}=41.69, p<0.0001\right)$, but no significant interaction between genotype and context (Fig. $3 C$ ). These data suggest a moderate, but significant deficit in context discrimination in mice with a pan-neuronal deletion of $\mathrm{Ca}_{\mathrm{v}} 1.2$, which can be overcome by training.

To further investigate the effects of neuronal deletion of $\mathrm{Ca}_{\mathrm{v}} 1.2$ in a more difficult spatial learning task, we assessed the performance of $\mathrm{Ca}_{\mathrm{v}} 1.2^{\mathrm{cKO}}$ mice in a version of the water maze that we refer to as the "limited cues" water maze. During the limited cues water maze, complex spatial cues around the room were eliminated using a blue plastic barrier, and, in their place, four discreet cues were spaced evenly around the maze (Fig. 4A). Mice were trained to the limited cues water maze using two $60 \mathrm{~s}$ training sessions per day, for $11 \mathrm{~d}$. Training sessions were performed as in the standard Morris water maze. Mice were probed for their preference for the platform location on day 9 , similar to the standard water maze, and on day 12, $24 \mathrm{~h}$ after the last training session.

Analysis of the latency to find the hidden platform across training using a repeated-measures ANOVA, and genotype and training day as factors, revealed a significant effect of both genotype $\left(F_{(1.30)}=12.362, p=0.0014\right)$ and training day $\left(F_{(13,390)}=8.343, p<0.0001\right)$ with $\mathrm{Ca}_{\mathrm{V}} 1.2^{\mathrm{CKO}}$ mice exhibiting a significant deficit in training compared with wild-type mice (Fig. 4B). While wild-type mice showed a decrease in latency to find the hidden platform from $52.097 \mathrm{~s}$ on day 1 to $21.923 \mathrm{~s}$ on day 11 , $\mathrm{Ca}_{\mathrm{V}} 1.2^{\mathrm{CKO}}$ mice only showed a minor improvement in latency to find the hidden platform from $53.348 \mathrm{~s}$ on day 
A

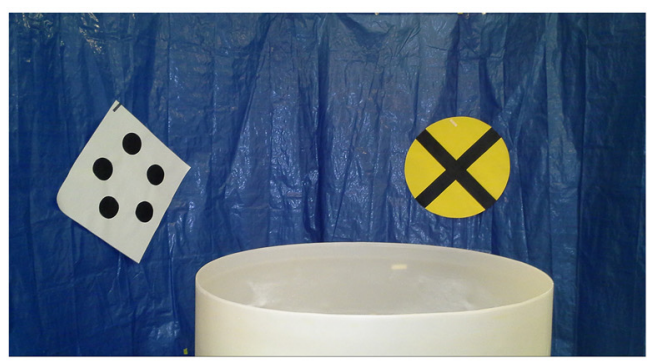

C

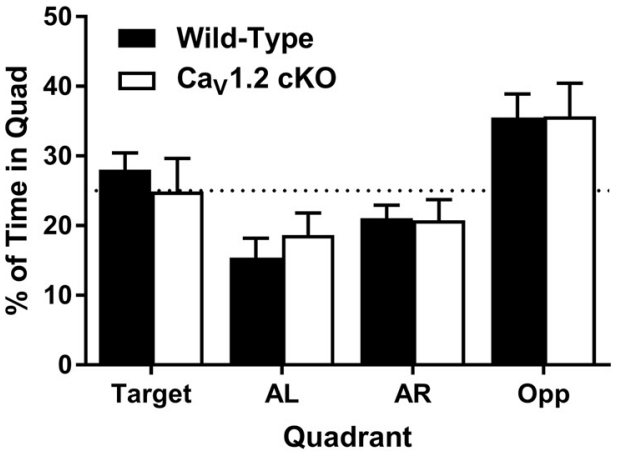

E

Probe Test 2

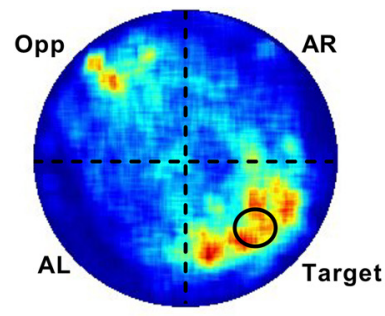

Wild-Type

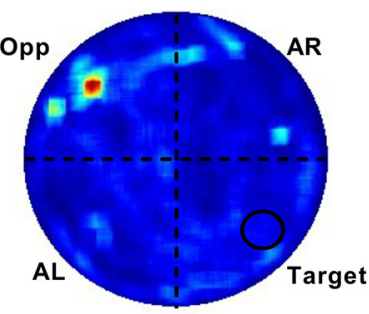

$\mathrm{Ca}_{\mathrm{v}} 1.2 \mathrm{cKO}$
B

Watermaze Training

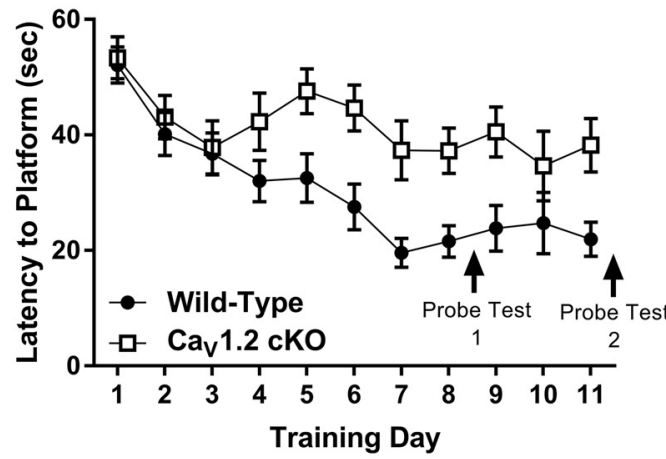

D

Probe Test 2

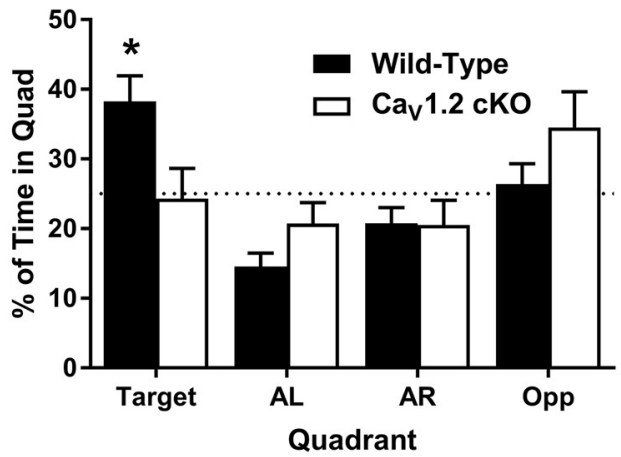

F

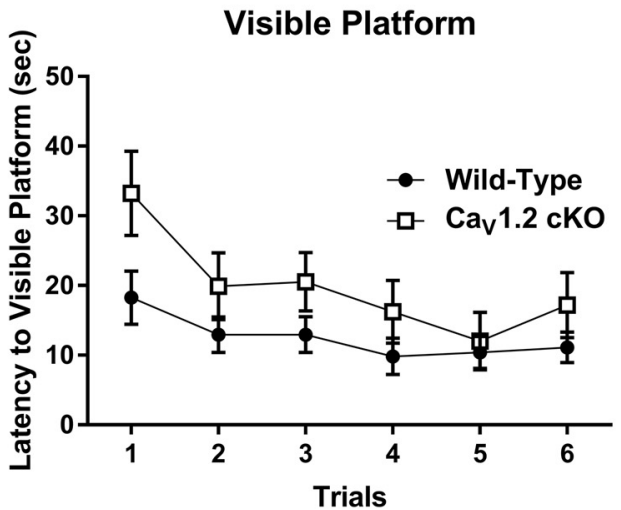

Figure 4. $\mathrm{Ca}_{\mathrm{V}} 1.2$ conditional knock-out mice exhibit significant impairments in the acquisition of spatial memory in the limited cues version of the Morris water maze. $\boldsymbol{A}$, To test for deficits in complex hippocampal learning, mice were tested in a version of the Morris water maze in which the visible cues around the room were limited. Mice were trained across $11 \mathrm{~d}$ and tested for their spatial memory of the platform location on days 9 and 12 of experimentation. $\boldsymbol{B}$, Across training, $\mathrm{Ca}_{\mathrm{v}} 1.2$ conditional knock-out mice $(n=14)$ exhibited a significant deficit in the latency to find the hidden platform compared with wild-type mice $(n=18)$. $\boldsymbol{C}$, During the first probe test, neither $\mathrm{Ca}_{\mathrm{v}} 1.2$ conditional knock-out mice nor wild-type mice exhibited a significant preference for the target quadrant compared with chance or the other quadrants. $\boldsymbol{D}$, During the second probe test, wild-type mice, but not $\mathrm{Ca}_{v} 1.2$ conditional knock-out mice, exhibited a significant preference for the target quadrant over the other quadrants and over chance [*p $<0.0001$, single-group $t$ test with a hypothetical mean of $25 \%$ (indicated by dashed line)]. $\boldsymbol{E}$, Heat maps for wild-type mice (left) and $\mathrm{Ca}_{\mathrm{v}} 1.2$ conditional knock-out mice (right) during probe trial 2. $\boldsymbol{F}$, When tested for their ability to find a visible platform, both $\mathrm{Ca}_{\mathrm{v}} 1.2$ conditional knock-out mice and wild-type mice were able to find the platform across six trials. Data are represented as the mean \pm SEM.

1 to 38.207 s on day 11. During probe test 1 , on day 9 of training, neither wild-type nor $\mathrm{Ca}_{\mathrm{v}} 1.2^{\mathrm{cKO}}$ mice showed a significant preference for the target quadrant, represented as a percentage of time, compared with chance $(p=0.23$ and $p=0.98$, respectively; one group $t$ test; Fig. $4 C$ ).
These data demonstrate that, after $8 \mathrm{~d}$ of training, neither $\mathrm{Ca}_{\mathrm{v}} 1.2^{\mathrm{CKO}}$ mice nor wild-type mice have a spatial memory for the platform location, and suggest that this version of the water maze is indeed more difficult to learn. During probe test 2 , on day 12 of experimentation, wild-type 

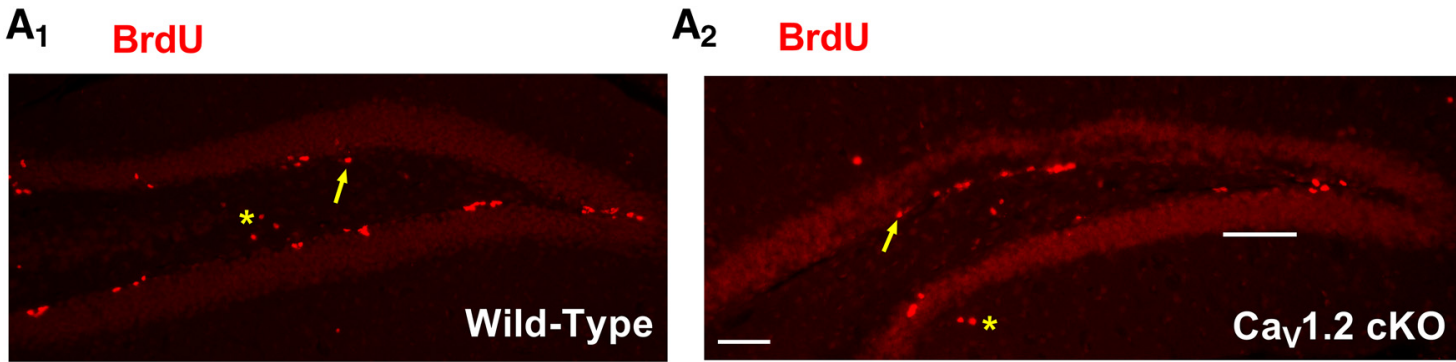

B

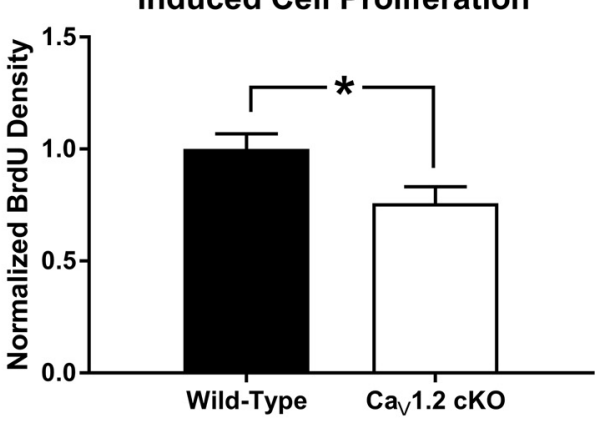

C

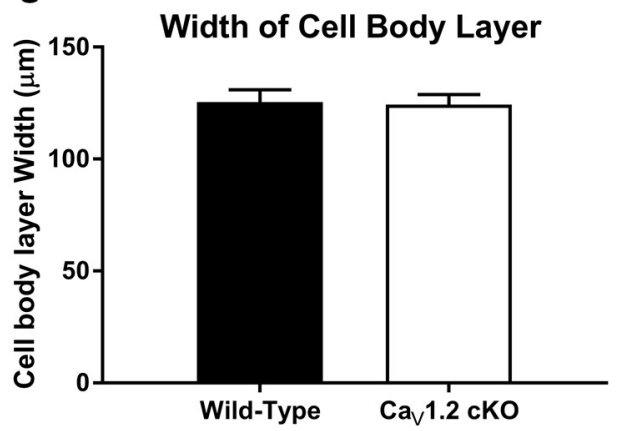

Figure 5. $\mathrm{Ca}_{\mathrm{v}} 1.2$ conditional knock-out mice exhibit decreased levels of cell division in the adult dentate gyrus. $\boldsymbol{A}_{\mathbf{1}}, \boldsymbol{A}_{\mathbf{2}}$, Ca 1.2 conditional knock-out mice $(n=10)$ and wild-type mice $(n=7)$ were also assessed for the rates of cell division in the adult dentate gyrus. Arrows indicate examples of BrdU-positive cells within the area of interest. Asterisks represent examples of cells outside of the area of interest. $\boldsymbol{B}$, Comparison of the density of BrdU-positive cells in the dentate gyrus between genotypes revealed a significant decrease in cell division in $\mathrm{Ca}_{\mathrm{v}} 1.2$ conditional knock-out mice vs wild-type mice. $\boldsymbol{C}, \mathrm{Ca}_{\mathrm{v}} 1.2$ conditional knock-out mice did not exhibit alterations in the width of the dentate gyrus. Data are represented as the mean \pm SEM. $* p<0.05$, unpaired $t$ test.

mice exhibited a significant preference for the target quadrant compared with chance $(p=0.0021$; Fig. $4 D, E$ ). However, $\mathrm{Ca}_{v} 1.2^{\mathrm{cKO}}$ mice did not spend significantly more time searching in the target quadrant compared with chance $(p=0.86)$. Furthermore, an unpaired $t$ test comparing the percentage of time spent in the target quadrant revealed a difference, with the wild-type mice spending significantly more time in the quadrant where the platform was previously located $(p=0.0189)$. These data suggest that wild-type mice, but not $\mathrm{Ca}_{\mathrm{v}} 1.2^{\mathrm{cKO}}$ mice, formed a spatial memory of the platform location. Following probe test 2, $\mathrm{Ca}_{\mathrm{v}} 1.2^{\mathrm{cKO}}$ mice and wild-type mice were tested for their ability to find a visible platform across six trials (Fig. $4 F$ ). Poor performance on the visible platform could suggest an inability for mice to properly view the spatial cues of the maze. Comparison of the latency to find the visible platform between genotypes using a repeatedmeasures ANOVA revealed no significant difference in latency to find the platform between genotypes $\left(F_{(1,30)}\right.$ $=2.424, p=0.1300$ ) but a significant effect of training trials $\left(F_{(5,150)}=3.010, p=0.0128\right)$, suggesting that deficits in spatial learning in $\mathrm{Ca}_{\mathrm{V}} 1.2^{\mathrm{cKO}}$ mice are not likely due to a deficit in their ability to see the visible cues or their ability to perform the task. Together, these data suggest that neuronal deletion of $\mathrm{Ca}_{v} 1.2$ produces deficits in difficult hippocampal tasks, such as those associated with dentate gyrus neurogenesis (Shors et al., 2002; Saxe et al., 2006).

\section{Neuronal deletion of $\mathrm{Ca}_{\mathrm{v}} 1.2$ impairs neurogenesis and cell division in the dentate gyrus}

Previous experiments using pharmacological methods have implicated LVGCCs in cell proliferation and neurogenesis prenatally (D'Ascenzo et al., 2006; Piacentini et al., 2008; Brustein et al., 2013) and into adulthood (Deisseroth et al., 2004; Luo et al., 2005; Zhu et al., 2012). In light of previous literature suggesting that context discrimination and difficult hippocampal tasks in general can be influenced by adult neurogenesis in the dentate gyrus (Saxe et al., 2006; Sahay et al., 2011) and the abundance of $\mathrm{Ca}_{\mathrm{v}} 1.2$ expression in the dentate (Hell et al., 1993), we hypothesized that the deficits we observed in the $\mathrm{Ca}_{\mathrm{v}} 1.2^{\mathrm{cKO}}$ mice might reflect changes in cell proliferation and neurogenesis in the dentate gyrus. To determine whether neuronal deletion of $\mathrm{Ca}_{\mathrm{v}} 1.2$ alters cell proliferation and adult neurogenesis, we labeled dividing cells in the dentate gyrus in naive mice using $5 \mathrm{~d}$ of $100 \mathrm{mg} / \mathrm{kg}$ BrdU (del Rio and Soriano, 1989) injections administered intraperitoneally. Twenty-four hours after the final BrdU injection, mice were perfused, and sections containing the subgranular zone of the dentate gyrus were collected and processed for BrdU using a red fluorescent secondary antibody (Fig. 5A1,A2 ). Cells that were BrdU positive were counted and normalized to the average density of BrdU in wild-type mice. Cell counts revealed that panneuronal deletion significantly reduced the number of BrdU-positive cells in $\mathrm{Ca}_{\mathrm{v}} 1.2^{\mathrm{cKO}}$ mice compared with wild-type mice ( $p=0.04$, unpaired $t$ test) with a decrease 
in BrdU-positive cell density of $24.2 \%$ in $\mathrm{Ca}_{\mathrm{V}} 1.2^{\mathrm{cKO}}$ mice (Fig. 5B). Analysis of the width of the cell body layer of the dentate gyrus (Fig. $5 C$ ) using an unpaired $t$ test revealed no significant difference between genotypes $(p=0.8782)$. These data suggest that $\mathrm{Ca}_{\mathrm{v}} 1.2$ plays an important role in cell proliferation in the adult dentate gyrus.

A recent report suggested that there is strong expression of $\mathrm{Ca}_{\mathrm{v}} 1.2$ in immature doublecortin-positive cells within the dentate gyrus (Marschallinger et al., 2015). Therefore, we wanted to determine whether the deletion of $\mathrm{Ca}_{v} 1.2$ could alter the number of newborn neurons within the dentate gyrus. To assess the number of newborn neurons within the dentate gyrus, we performed immunohistochemistry for doublecortin (Brown et al., 2003; Fig. 6A). Similar to BrdU studies, doublecortin analysis was limited to the subgranular zone of the dentate gyrus. Analysis of the number of immature neurons in the dentate gyrus using doublecortin staining in the dentate gyrus revealed a significant decrease in the density of doublecortin-labeled cells $(p=0.04)$, with $\mathrm{Ca}_{v} 1.2^{\mathrm{cKO}}$ mice exhibiting a decrease in doublecortin-labeled cells of $34.7 \%$ compared with wild-type mice (Fig. 6B). Although it remains unclear whether $\mathrm{Ca}_{v} 1.2$ alters the number of immature neurons via a role in differentiation, early neuronal survival, or cell proliferation, our data suggest that pan-neuronal deletion of $\mathrm{Ca}_{\mathrm{v}} 1.2$ decreases the number of newborn neurons in the dentate gyrus. Together, the deletion of $\mathrm{Ca}_{\mathrm{v}} 1.2$ alters the number of newborn neurons and the rate of cell proliferation in the dentate gyrus, which could result in deficits in hippocampal-dependent learning, such as those seen in $\mathrm{Ca}_{\mathrm{v}} 1.2^{\mathrm{cKO}}$ mice.

\section{Discussion}

Using transgenic mice with a pan-neuronal deletion of the LVGCC Ca 1.2 , we investigated the role of $\mathrm{Ca}_{v} 1.2$ in hippocampal-dependent learning and cognition, with a focus on simple versus complex tasks. Because of the implication of the dentate gyrus in cognitively demanding tasks along with previous literature suggesting a role of LVGCCs in neural differentiation, and the abundance of $\mathrm{Ca}_{\mathrm{V}} 1.2$ expression in the dentate gyrus compared with other parts of the hippocampus, we also examined the effects of the deletion of $\mathrm{Ca}_{\mathrm{v}} 1.2$ on cell proliferation and neurogenesis in the dentate gyrus.

We tested $\mathrm{Ca}_{\mathrm{V}} 1.2^{\mathrm{cKO}}$ mice in two types of simple hippocampal-dependent learning tasks: Pavlovian fear conditioning and the standard Morris water maze. $\mathrm{Ca}_{\mathrm{v}} 1.2^{\mathrm{cKO}}$ mice exhibited normal acquisition, consolidation, and expression of context-based fear memories. Additionally, $\mathrm{Ca}_{\mathrm{v}} 1.2^{\mathrm{cKO}}$ mice acquired a spatial memory of the location of a hidden platform in the standard Morris water maze at rates and levels that were comparable to those observed in wild-type mice. However, when tested in the context discrimination task, $\mathrm{Ca}_{\mathrm{v}} 1.2^{\mathrm{cKO}}$ mice exhibited a significant deficit in the ability to discriminate two contexts throughout training. When tested in the limited cues water maze, in which the number and diversity of spatial cues are limited compared with the standard water maze, $\mathrm{Ca}_{\mathrm{v}} 1.2^{\mathrm{cKO}}$ mice exhibited significant deficits in the
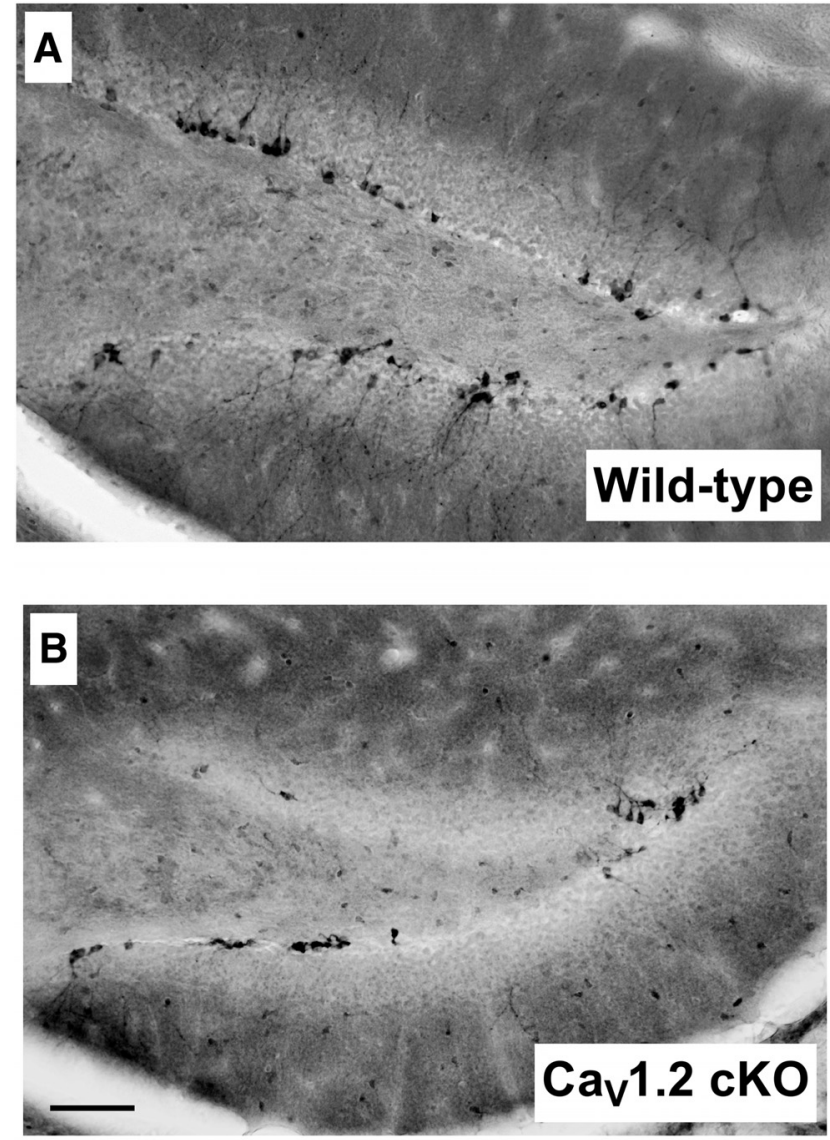

C

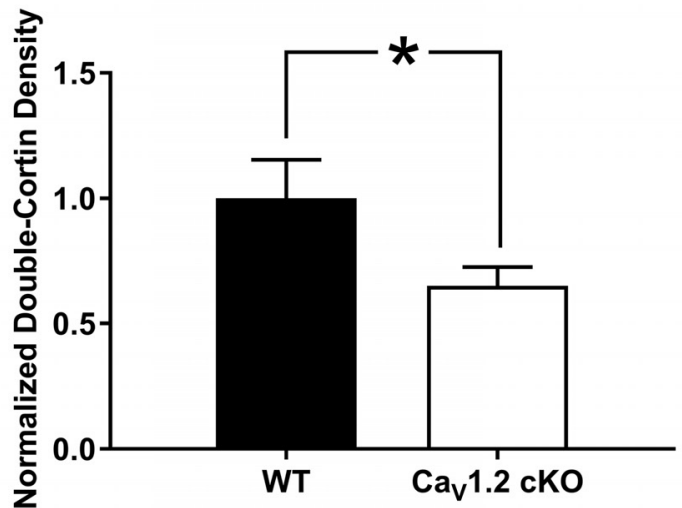

Figure 6. $\mathrm{Ca}_{\mathrm{V}} 1.2$ conditional knock-out mice exhibit decreased levels of immature neurons in the adult dentate gyrus. $\boldsymbol{A}, \boldsymbol{B}$, Both $\mathrm{Ca}_{\mathrm{V}} 1.2$ conditional knock-out mice $(n=10)$ and wild-type mice $(n=7)$ were assessed for adult-born immature neurons in the dentate gyrus through immunohistological labeling of doublecortin-positive cells in the subgranular zone of the dentate gyrus. $\boldsymbol{C}$, Analysis of the density of doublecortin-positive cells revealed a significant decrease in adult-born immature neurons in $\mathrm{Ca}_{\mathrm{v}} 1.2$ conditional knock-out mice compared with wild-type mice. Data are represented as the mean \pm SEM. $* p<0.05$, unpaired $t$ test.

latency to find the hidden platform compared with wildtype mice and failed to show a preference for the target quadrant when probed for their memory for the platform location. 
Previous studies investigating the role of $\mathrm{Ca}_{\mathrm{V}} 1.2$ in hippocampal-dependent learning have yielded conflicting results. While the deletion of $\mathrm{Ca}_{\mathrm{v}} 1.2$ in excitatory neurons did not alter behavioral performances in the Morris water maze and contextual fear conditioning in one set of article (McKinney et al., 2008; White et al., 2008), it did produce deficits in a version of the Morris Water maze termed the water maze spatial-discrimination task and the labyrinth maze in another (Moosmang et al., 2005). Though these conflicting results could be attributed to differences in the transgenic models used, our studies suggest that both sets of data may be valid, with one set supporting the simple hippocampal tasks and behavioral results found in our mice with neuronal deletions of $\mathrm{Ca}_{\mathrm{v}} 1.2$, while the other set of results may reflect the role of $\mathrm{Ca}_{\mathrm{v}} 1.2$ in more complex versions of hippocampal learning. In the water maze spatial-discrimination task, mice must learn to discriminate the spatial location of two visible platforms, one that is fixed and another that sinks (Arns et al., 1999; Steckler et al., 1999; Kleppisch et al., 2003; Moosmang et al., 2005). In the labyrinth maze, mice learned to transverse a brightly lit maze in order to be returned to their shadowed home cages. The maze was made up of nine intersections at which point mice must make a spatial decision in direction (Tang et al., 1999; Moosmang et al., 2005). Though the exact difficulty of these tasks compared with other hippocampal-dependent tasks is hard to assess, impairments of $\mathrm{Ca}_{\mathrm{v}} 1.2$ in difficult but not simple hippocampal learning tasks may explain the discrepancy in results found in previous articles.

In previous studies, our selected simple hippocampaldependent learning tasks have been found to be dependent on the hippocampus proper, but independent of neurogenesis in the dentate gyrus. Previous studies investigating the role of neurogenesis within the dentate gyrus in learning and memory have suggested that decreased neurogenesis has no effect on contextual fear conditioning or the standard Morris water maze (Shors et al., 2002; Jaholkowski et al., 2009). In addition, we defined our difficult hippocampal tasks as similar tasks, which involved similar brain structures, but were more cognitively challenging and therefore required additional training in order to learn. Studies suggest that hippocampal-dependent tasks that are more difficult are more likely to require the dentate gyrus and adult-born neurons within this structure (Shors et al., 2002). This appears to be the case for context discrimination in which decreases in neurogenesis impair the ability of an animal to learn to discriminate between two contexts (Saxe et al., 2006), while increases in neurogenesis enhance the performance of an animal in this task (Nakashiba et al., 2012). Although there is no direct literature investigating the effects of adult neurogenesis on the limited cues water maze, we believe that the limited cues water maze is more difficult than the standard water maze. We found that, while wild-type mice were able to learn the location of a hidden platform in the standard Morris water maze after only $8 \mathrm{~d}$ of training, wild-type mice trained in the limited cues version of the water maze exhibited chance performance after $8 \mathrm{~d}$ of training and required an additional $3 \mathrm{~d}$ of training (six additional training sessions) to learn the location of the platform.

In light of reports linking difficult hippocampaldependent learning tasks and the birth of new neurons in the dentate gyrus (Shors et al., 2002), in particular the strong link drawn between context discrimination and neurogenesis (Saxe et al., 2006; Nakashiba et al., 2012), we examined the putative role of $\mathrm{Ca}_{\mathrm{v}} 1.2$ in cell proliferation and adult neurogenesis in the dentate gyrus. We found that in naive mice cell proliferation in the dentate gyrus (assessed using BrdU) was reduced, as was the number of doublecortin-positive cells. We believe that these decreases in cell proliferation and immature neurons in $\mathrm{Ca}_{\mathrm{v}} 1.2^{\mathrm{cKO}}$ mice could produce deficits in hippocampal learning that are dependent on the dentate gyrus, such as in context discrimination and the limited cues water maze. Using pharmacological blockade, studies have linked LVGCCs with cell proliferation and neurogenesis prenatally (D'Ascenzo et al., 2006; Piacentini et al., 2008; Brustein et al., 2013) and into adulthood (Deisseroth et al., 2004; Luo et al., 2005; Zhu et al., 2012). In the case of adult neurogenesis, studies found that the blockade of LVGCCs did prevent induced cell proliferation (Zhu et al., 2012) and neurogenesis (Deisseroth et al., 2004; Luo et al., 2005). These results are furthered by a recent study demonstrating that a loss of $\mathrm{Ca}_{\mathrm{v}} 1.2$ decreased the survival rate of adult-born neurons in the dentate gyrus (Kang et al., 2015; Lee et al., 2016). Additionally, the activation of LVGCCs using channel agonists increased the percentage of neural progenitor cells that survived to become adult neurons (Deisseroth et al., 2004). While previous studies have found large levels of $\mathrm{Ca}_{\mathrm{V}} 1.2$ expression in the adult dentate gyrus, $\mathrm{Ca}_{\mathrm{v}} 1.2$ has not been found in neural stem cells (Deisseroth et al., 2004; Marschallinger et al., 2015). This suggests that $\mathrm{Ca}_{\mathrm{V}} 1.2$ may be altering cell proliferation via its effects on neuronal activity within the dentate gyrus associated with cell proliferation. Based on these results, $\mathrm{Ca}_{\mathrm{V}} 1.2$ is capable of modulating cell proliferation in the adult dentate gyrus and does so in a cell-specific manner. Previous studies have found $\mathrm{Ca}_{\mathrm{v}} 1.2$ to be expressed in doublecortin-positive cells in the dentate gyrus. (Marschallinger et al., 2015). Therefore, $\mathrm{Ca}_{\mathrm{v}} 1.2$ could also be altering the number of immature neurons via the loss of $\mathrm{Ca}_{\mathrm{v}} 1.2$ in the immature neurons themselves. These results are similar to previous studies in which the deletion of $\mathrm{Ca}_{\mathrm{v}} 1.3$ resulted in a decrease in doublecortin-positive and the number of BrdU-positive cells after 4 weeks (Marschallinger et al., 2015). Therefore, both $\mathrm{Ca}_{\mathrm{v}} 1.2$ and $\mathrm{Ca}_{\mathrm{v}} 1.3$ appear to be involved in adult neurogenesis.

Interestingly, these results were seen in the absence of a change in the average width of the dentate gyrus, which may suggest normal dentate gyrus neurogenesis and formation in the absence of $\mathrm{Ca}_{\mathrm{v}} 1.2$ early in development, despite the decrease in adult neurogenesis in $\mathrm{Ca}_{\mathrm{V}} 1.2^{\mathrm{CKO}}$ mice. Potentially, this could be due to the limited expression of $\mathrm{Ca}_{\mathrm{v}} 1.2$ prenatally compared with postnatally or the influence of neuronal circuitry on adult neurogenesis that is not present prenatally. Despite these implications, we cannot rule out the potential effects of a loss of $\mathrm{Ca}_{\mathrm{v}} 1.2$ on 
prenatal neurogenesis or the postnatal development of the dentate gyrus based on our results alone. First, while steps were taken to measure the width of the dentate gyrus across the entire length of the structure, it is possible that alterations in neuron number could have been missed or occurred in a way that did not alter the actual width of the structure. In fact, it could be an interaction of alterations in adult and perinatal neurogenesis in the absence of $\mathrm{Ca}_{\mathrm{v}} 1.2$ that could be producing the behavioral deficits. In addition, it is possible that the methods in which mice were treated prior to tissue collection could have impacted dentate gyrus width or cell proliferation detected by BrdU and doublecortin. For example, the use of anesthetics has been linked with alterations in brain physiology and adult neurogenesis (Stratmann et al., 2009; Zhu et al., 2010; Erasso et al., 2013), although the use of anesthetics in our experiments was limited to $30 \mathrm{~s}$ of isoflurane exposure on each occasion, which is substantially different than the 3-8 $\mathrm{h}$ of aerosolized anesthetic found to alter neurophysiology in previous studies. Additionally, all environmental and temporal features of the experiments performed, particularly regarding the investigation of dentate gyrus structure, were tightly controlled to eliminate variability between mice and groups as much as possible. Finally, we must concede the unlikely possibility that, because our cell-counting experiments were not strictly adherent to unbiased stereology principles, it is possible that the observed differences in the $\mathrm{Ca}_{\mathrm{V}} 1.2^{\mathrm{cKO}}$ mice might be due to genotype-specific changes in the anatomical structure of the dentate gyrus.

The data presented here provide strong evidence that $\mathrm{Ca}_{\mathrm{V}} 1.2$ does in fact play a role in hippocampal-dependent learning. However, $\mathrm{Ca}_{\mathrm{v}} 1.2$ is required only for tasks that are more cognitively demanding. This may reflect the differential expression pattern of $\mathrm{Ca}_{\vee} 1.2$ within the hippocampus. Additionally, we have demonstrated an important role of $\mathrm{Ca}_{\mathrm{v}} 1.2$ in modulating cell proliferation and adult neurogenesis in the hippocampal structure, the dentate gyrus, with this modulation as a candidate mechanism by which $\mathrm{Ca}_{\mathrm{v}} 1.2$ mediates complex, but not simple, hippocampal-dependent learning.

Interestingly, a number of genome-wide association studies have linked single nucleotide polymorphisms (SNPs) in CACNA1C to several psychiatric disorders (Sklar et al., 2008), and it has been variously suggested that these SNPs are putative neuropsychiatric risk alleles (Bhat et al., 2012). Although the majority of studies have implicated these risk alleles in bipolar disorder, a number of studies suggest that variations in CACNA1C are associated with major depression, schizophrenia, and autism (Green et al., 2010; Nyegaard et al., 2010; Li et al., 2015). Furthermore, there is mounting evidence that CACNA1C risk alleles may be associated with deficits in the processing of emotional information (Soeiro-de-Souza et al., 2012; Nieratschker et al., 2015). This, coupled with the emerging idea that adult neurogenesis may contribute to psychiatric disorders, including schizophrenia (Kang et al., 2015), leads us to speculate that a disruption in $\mathrm{Ca}_{\mathrm{V}} 1.2$ function or expression may play a significant role not only in cognition, but also in neuropsychiatric disor- ders by altering adult neurogenesis and degrading dentate gyrus function.

\section{References}

Altman J, Das GD (1965) Autoradiographic and histological evidence of postnatal hippocampal neurogenesis in rats. J Comp Neurol 124:319-335. Medline

Arns M, Sauvage M, Steckler T (1999) Excitotoxic hippocampal lesions disrupt allocentric spatial learning in mice: effects of strain and task demands. Behav Brain Res 106:151-164. Medline

Bauer EP, Schafe GE, LeDoux JE (2002) NMDA receptors and L-type voltage-gated calcium channels contribute to long-term potentiation and different components of fear memory formation in the lateral amygdala. J Neurosci 22:5239-5249. Medline

Bhat S, Dao DT, Terrillion CE, Arad M, Smith RJ, Soldatov NM, Gould TD (2012) CACNA1C $\left(\mathrm{Ca}_{v} 1.2\right)$ in the pathophysiology of psychiatric disease. Prog Neurobiol 99:1-14. CrossRef Medline

Brown JP, Couillard-Després S, Cooper-Kuhn CM, Winkler J, Aigner L, Kuhn HG (2003) Transient expression of doublecortin during adult neurogenesis. J Comp Neurol 467:1-10. CrossRef Medline

Brustein E, Côté S, Ghislain J, Drapeau P (2013) Spontaneous glycine-induced calcium transients in spinal cord progenitors promote neurogenesis. Dev Neurobiol 73:168-175. CrossRef Medline

Cain CK, Blouin AM, Barad M (2002) L-type voltage-gated calcium channels are required for extinction, but not for acquisition or expression, of conditional fear in mice. J Neurosci 22:9113-9121. Medline

Cui Y, Costa RM, Murphy GG, Elgersma Y, Zhu Y, Gutmann DH, Parada LF, Mody I, Silva AJ (2008) Neurofibromin regulation of ERK signaling modulates GABA release and learning. Cell 135: 549-560. CrossRef Medline

D'Ascenzo M, Piacentini R, Casalbore P, Budoni M, Pallini R, Azzena GB, Grassi C (2006) Role of L-type Ca2+ channels in neural stem/progenitor cell differentiation. Eur J Neurosci 23:935-944.

Davis SE, Bauer EP (2012) L-type voltage-gated calcium channels in the basolateral amygdala are necessary for fear extinction. J Neurosci 32:13582-13586. CrossRef Medline

Deisseroth K, Heist EK, Tsien RW (1998) Translocation of calmodulin to the nucleus supports CREB phosphorylation in hippocampal neurons. Nature 392:198-202. CrossRef Medline

Deisseroth K, Singla S, Toda H, Monje M, Palmer TD, Malenka RC (2004) Excitation-neurogenesis coupling in adult neural stem/progenitor cells. Neuron 42:535-552. Medline

del Rio JA, Soriano E (1989) Immunocytochemical detection of 5'bromodeoxyuridine incorporation in the central nervous system of the mouse. Brain Res Dev Brain Res 49:311-317. Medline

Erasso DM, Camporesi EM, Mangar D, Saporta S (2013) Effects of isoflurane or propofol on postnatal hippocampal neurogenesis in young and aged rats. Brain Res 1530:1-12. CrossRef Medline

Gage FH (2002) Neurogenesis in the adult brain. J Neurosci 22:612613. Medline

Gould E, Beylin A, Tanapat P, Reeves A, Shors TJ (1999) Learning enhances adult neurogenesis in the hippocampal formation. Nat Neurosci 2(3):260-265. Medline

Green EK, Grozeva D, Jones I, Jones L, Kirov G, Caesar S, GordonSmith K, Fraser C, Forty L, Russell E, Hamshere ML, Moskvina V, Nikolov I, Farmer A, McGuffin P, Holmans PA, Owen MJ, O'Donovan MC, Craddock N (2010) The bipolar disorder risk allele at CACNA1C also confers risk of recurrent major depression and of schizophrenia. Mol Psychiatry 15:1016-1022. CrossRef Medline

Hell JW, Westenbroek RE, Warner C, Ahlijanian MK, Prystay W, Gilbert MM, Snutch TP, Catterall WA (1993) Identification and differential subcellular localization of the neuronal class $C$ and class D L-type calcium channel alpha 1 subunits. J Cell Biol 123:949-962. CrossRef

Jaholkowski $P$, Kiryk A, Jedynak $P$, Ben Abdallah NM, Knapska $E$, Kowalczyk A, Piechal A, Blecharz-Klin K, Figiel I, Lioudyno V, Widy-Tyszkiewicz E, Wilczynski GM, Lipp HP, Kaczmarek L, Filip- 
kowski RK (2009) New hippocampal neurons are not obligatory for memory formation; cyclin D2 knockout mice with no adult brain neurogenesis show learning. Learn Mem 16:439-451. CrossRef

Kaczorowski CC (2011) Bidirectional pattern-specific plasticity of the slow afterhyperpolarization in rats: role for high-voltage activated $\mathrm{Ca}^{2+}$ channels and I h. Eur J Neurosci 34:1756-1765. CrossRef Medline

Kang E, Wen Z, Song H, Christian KM, Ming G-I (2015) Adult neurogenesis and psychiatric disorders. Cold Spring Harb Perspect Biol 8:a019026. CrossRef

Kapur A, Yeckel MF, Gray R, Johnston D (1998) L-type calcium channels are required for one form of hippocampal mossy fiber LTP. J Neurophysiol 79:2181-2190. Medline

Kleppisch T, Wolfsgruber W, Feil S, Allmann R, Wotjak CT, Goebbels S, Nave KA, Hofmann F, Feil R (2003) Hippocampal cGMPdependent protein kinase I supports an age- and protein synthesis-dependent component of long-term potentiation but is not essential for spatial reference and contextual memory. J Neurosci 23:6005-6012. Medline

Langwieser N, Christel CJ, Kleppisch T, Hofmann F, Wotjak CT, Moosmang S (2010) Homeostatic switch in hebbian plasticity and fear learning after sustained loss of $\mathrm{Ca}_{\mathrm{v}} 1.2$ calcium channels. J Neurosci 30:8367-8375. CrossRef Medline

Lee AS, De Jesus-Cortes H, Kabir ZD, Knobbe W, Orr M, Burgdorf C, Huntington P, McDaniel L, Britt JK, Hoffmann F, Brat DJ, Rajadhyaksha AM, Pieper AA (2016) The neuropsychiatric diseaseassociated gene cacna1c mediates survival of young hippocampal neurons. eNeuro 10.1523/ENEURO.0006-16.2016

Li J, Zhao L, You Y, Lu T, Jia M, Yu H, Ruan Y, Yue W, Liu J, Lu L, Zhang D, Wang $L$ (2015) Schizophrenia related variants in CACNA1C also confer risk of autism. PLoS One 10:e0133247 CrossRef Medline

Lipscombe D, Helton TD, Xu W (2004) L-type calcium channels: the low down. J Neurophysiol 92:2633-2641. CrossRef Medline

Logue SF, Paylor R, Wehner JM (1997) Hippocampal lesions cause learning deficits in inbred mice in the Morris water maze and conditioned-fear task. Behav Neurosci 111:104-113. Medline

Luo CX, Zhu XJ, Zhang AX, Wang W, Yang XM, Liu SH, Han X, Sun J, Zhang SG, Lu Y, Zhu DY (2005) Blockade of L-type voltagegated $\mathrm{Ca}$ channel inhibits ischemia-induced neurogenesis by down-regulating iNOS expression in adult mouse. J Neurochem 94:1077-1086. CrossRef Medline

Maren S, Aharonov G, Fanselow MS (1997) Neurotoxic lesions of the dorsal hippocampus and Pavlovian fear conditioning in rats. Behav Brain Res 88:261-274. Medline

Marschallinger J, Sah A, Schmuckermair C, Unger M, Rotheneichner P, Kharitonova M, Waclawiczek A, Gerner P, JakschBogensperger H, Berger S, Striessnig J, Singewald N, CouillardDespres S, Aigner L (2015) The L-type calcium channel $\mathrm{Ca}_{\mathrm{V}} 1.3$ is required for proper hippocampal neurogenesis and cognitive functions. Cell Calcium 58:606-616. CrossRef Medline

McKinney BC, Murphy GG (2006) The L-Type voltage-gated calcium channel $\mathrm{Ca}_{\mathrm{v}} 1.3$ mediates consolidation, but not extinction, of contextually conditioned fear in mice. Learn Mem 13:584-589. CrossRef

McKinney BC, Sze W, White JA, Murphy GG (2008) L-type voltagegated calcium channels in conditioned fear: a genetic and pharmacological analysis. Learn Mem 15:326-334. CrossRef Medline

Moosmang S, Haider N, Klugbauer N, Adelsberger H, Langwieser N, Müller J, Stiess M, Marais E, Schulla V, Lacinova L, Goebbels S, Nave KA, Storm DR, Hofmann F, Kleppisch T (2005) Role of hippocampal $\mathrm{Ca}_{\mathrm{v}} 1.2 \mathrm{Ca}^{2+}$ channels in NMDA receptorindependent synaptic plasticity and spatial memory. J Neurosci 25:9883-9892. CrossRef Medline

Morris R (1984) Developments of a water-maze procedure for studying spatial learning in the rat. J Neurosci Methods 11:47-60. CrossRef

Nakashiba T, Cushman JD, Pelkey KA, Renaudineau S, Buhl DL, McHugh TJ, Rodriguez Barrera V, Chittajallu R, Iwamoto KS,
McBain CJ, Fanselow MS, Tonegawa S (2012) Young dentate granule cells mediate pattern separation, whereas old granule cells facilitate pattern completion. Cell 149:188-201. CrossRef Medline

Nieratschker V, Brückmann C, Plewnia C (2015) CACNA1C risk variant affects facial emotion recognition in healthy individuals. Sci Rep 5:17349. CrossRef Medline

Nyegaard M, Demontis D, Foldager L, Hedemand A, Flint TJ, Sørensen KM, Andersen PS, Nordentoft M, Werge T, Pedersen CB, Hougaard DM, Mortensen PB, Mors O, Børglum AD (2010) CACNA1C (rs1006737) is associated with schizophrenia. Mol Psychiatry 15:119-121. CrossRef Medline

Piacentini R, Ripoli C, Mezzogori D, Azzena GB, Grassi C (2008) Extremely low-frequency electromagnetic fields promote in vitro neurogenesis via upregulation of $\mathrm{Ca}(\mathrm{v}) 1$-channel activity. J Cell Physiol 215:129-139. CrossRef

Sahay A, Scobie KN, Hill AS, O'Carroll CM, Kheirbek MA, Burghardt NS, Fenton AA, Dranoversusky A, Hen R (2011) Increasing adult hippocampal neurogenesis is sufficient to improve pattern separation. Nature 472:466-470. CrossRef Medline

Saxe MD, Battaglia F, Wang JW, Malleret G, David DJ, Monckton JE, Garcia AD, Sofroniew MV, Kandel ER, Santarelli L, Hen R, Drew MR (2006) Ablation of hippocampal neurogenesis impairs contextual fear conditioning and synaptic plasticity in the dentate gyrus. Proc Natl Acad Sci U S A 103:17501-17506. CrossRef Medline

Shors TJ, Townsend DA, Zhao M, Kozorovitskiy Y, Gould E (2002) Neurogenesis may relate to some but not all types of hippocampal-dependent learning. Hippocampus 12:578-584. CrossRef

Sklar P, Smoller JW, Fan J, Ferreira MA, Perlis RH, Chambert K, Nimgaonkar VL, McQueen MB, Faraone SV, Kirby A, de Bakker PI, Ogdie MN, Thase ME, Sachs GS, Todd-Brown K, Gabriel SB, Sougnez C, Gates C, Blumenstiel B, Defelice M, et al. (2008) Whole-genome association study of bipolar disorder. Mol Psychiatry 13:558-569. CrossRef Medline

Soeiro-de-Souza MG, Otaduy MCG, Dias CZ, Bio DS, MachadoVieira R, Moreno RA (2012) The impact of the CACNA1C risk allele on limbic structures and facial emotions recognition in bipolar disorder subjects and healthy controls. J Affect Disord 141:94101. CrossRef

Steckler T, Weis C, Sauvage M, Mederer A, Holsboer F (1999) Disrupted allocentric but preserved egocentric spatial learning in transgenic mice with impaired glucocorticoid receptor function. Behav Brain Res 100:77-89. Medline

Stratmann G, Sall JW, May LD, Bell JS, Magnusson KR, Rau V, Visrodia KH, Alvi RS, Ku B, Lee MT, Dai R (2009) Isoflurane differentially affects neurogenesis and long-term neurocognitive function in 60-day-old and 7-day-old rats. Anesthesiology 110: 834-848. CrossRef Medline

Tang YP, Shimizu E, Dube GR, Rampon C, Kerchner GA, Zhuo M, Liu G, Tsien JZ (1999) Genetic enhancement of learning and memory in mice. Nature 401:63-69. CrossRef Medline

Temme JEG, Wabel TM, Skiba AW, Driscoll JF (2015) Measurements of premixed turbulent combustion regimes of high Reynolds number flames. Paper presented at the 53rd AIAA Aerospace Sciences Meeting, Kissimmee, FL, January.

Temme SJ, Bell RZ, Pahumi R, Murphy GG (2014) Comparison of inbred mouse substrains reveals segregation of maladaptive fear phenotypes. Front Behav Neurosci 8:282. CrossRef Medline

Winocur G, Wojtowicz JM, Sekeres M, Snyder JS, Wang S (2006) Inhibition of neurogenesis interferes with hippocampus-dependent memory function. Hippocampus 16(3):296-304. Medline

White JA, McKinney BC, John MC, Powers PA, Kamp TJ, Murphy GG (2008) Conditional forebrain deletion of the L-type calcium channel Ca V 1.2 disrupts remote spatial memories in mice. Learn Mem 15:1-5. CrossRef Medline

Zakharenko SS, Zablow L, Siegelbaum SA (2001) Visualization of changes in presynaptic function during long-term synaptic plasticity. Nat Neurosci 4:711-717. CrossRef Medline

Zhu C, Gao J, Karlsson N, Li Q, Zhang Y, Huang Z, Li H, Kuhn HG, 
Blomgren K (2010) Isoflurane anesthesia induced persistent, progressive memory impairment, caused a loss of neural stem cells, and reduced neurogenesis in young, but not adult, rodents. $J$ Cereb Blood Flow Metab 30:1017-1030. CrossRef

Zhu Y, Romero MI, Ghosh P, Ye Z, Charnay P, Rushing EJ, Marth JD, Parada LF (2001) Ablation of NF1 function in neurons induces abnormal development of cerebral cortex and reactive gliosis in the brain. Genes Dev 15:859-876. CrossRef Medline

Zhu Y, Zhou R, Yang R, Zhang Z, Bai Y, Chang F, Li L, Sokabe M, Goltzman D, Miao D, Chen L (2012) Abnormal neurogenesis in the dentate gyrus of adult mice lacking 1,25-dihydroxy vitamin D3 (1,25-(OH)2 D3). Hippocampus 22:421-433. CrossRef Medline 